\title{
Vídeo em Libras: um estudo sobre produção e consumo de material audiovisual para a educação de surdos
}

Maria Inês Batista Barbosa Ramo

Luiz Augusto Coimbra de Rezende Filho

\section{Resumo}

O presente artigo apresenta o resultado de uma pesquisa que buscou identificar que leituras professores da rede regular de ensino fazem do vídeo em Libras "Sinalizando a Sexualidade", produzido pelo Instituto Nacional de Educação de Surdos. Inicialmente, por meio da metodologia da análise fílmica francesa e entrevista com os produtores, buscamos conhecer o significado preferencial e o endereçamento do vídeo. Por fim, a aplicação de um questionário mostrou as leituras dos professores que assumiram o lugar de espectador. A análise fílmica e a entrevista com os produtores mostraram que o vídeo é endereçado, principalmente, à comunidade surda, mas também aos professores que podem trabalhar com seus alunos surdos questões sobre sexo seguro. A análise dos questionários mostrou que os professores tiveram uma leitura convergente ao desejado pelos produtores. No entanto, dois professores mantiveram de forma mais clara um certo distanciamento crítico com relação à narrativa e à duração do vídeo.

Palavras-chave: Inclusão; Surdez; Material audiovisual.

\begin{abstract}
This article presents the outcomes of a study that aimed identifying regular schoolteachers' readings of an educational video called "Signing Sexuality", produced by the Brazilian National Institute of Education for the Deaf. Initially through film analysis and interviews with producers we seek to know the preferred meaning and the mode of address of the video. Finally, the application of a questionnaire showed what readings teachers did. The film analysis and interviews with producers showed that the video is addressed primarily to the deaf community, but also to teachers who can work with their deaf students questions about safe sex using audiovisual material in the Brazilian Sign Language (LIBRAS). Analysis of the questionnaires showed that teachers had a convergent reading as desired by the producers. Nevertheless, two teachers kept a certain critical distance with respect to the narrative and length of the video.
\end{abstract}

Keywords: inclusion; deafness; audiovisual material. 


\section{Introdução}

Nas últimas décadas, a escola vem buscando cumprir com o seu papel de instituição social ao alcance de "todos", promovendo por meio da política de inclusão (UNESCO, 1994; Política Nacional de Educação Especial na Perspectiva da Educação Inclusiva, 2008) uma proposta em que todos os atores envolvidos na cena educacional (gestores, professores, alunos e pais) tenham uma participação na construção de um espaço que acolha as diferenças e propicie uma educação de qualidade. Não devemos e nem podemos negar a diferença, mas compreender que elas fazem parte da diversidade humana. Quando esta diversidade está presente na escola, de acordo com as políticas públicas, a organização dos serviços, a formação de profissionais e a elaboração de projetos político pedagógicos devem favorecer o envolvimento de todos nesta proposta (FERREIRA e ALVES, 2007; VASQUES e BAPTISTA, 2006; Política Nacional de Educação Especial na perspectiva da Educação Inclusiva, 2008 e Plano Nacional de Educação, 2013).

Com a política de inclusão, tem sido cada vez mais frequente a presença de alunos surdos em diversos níveis de escolarização. Esta realidade impõe ao sistema educacional o desenvolvimento de metodologias e ferramentas que possibilitem e efetivem a inclusão desses alunos no processo de ensino-aprendizagem. O oferecimento de materiais audiovisuais adequadamente elaborados é um caminho para que o surdo possa ter uma autonomia discursiva e crítica nesse processo.

Com a proposta de contribuir para a investigação sobre os usos de materiais audiovisuais na educação de surdos, este artigo traz os resultados de uma pesquisa que, por meio de uma visão holística, ou seja, olhando simultaneamente para aspectos relacionados à produção e à recepção de um vídeo (denominado "Sinalizando a Sexualidade" e produzido em 2000 pelo Instituto Nacional de Educação de Surdos - INES), buscou identificar o endereçamento e o significado preferencial pretendido pelos produtores. Conhecendo a obra e as intenções de seus produtores, o passo seguinte do trabalho foi buscar as leituras dos professores para sabermos como o material audiovisual, na perspectiva desses professores, constrói um lugar de espectador para o surdo e endereça a ele informações sobre educação em saúde e sexualidade do jovem.

A escolha de trabalhar com os professores se deve ao fato de serem eles os agentes pedagógicos que irão apresentar este material aos surdos e, portanto, a visão que o professor tem sobre o uso de um material audiovisual em sala e as estratégias que utiliza para sua apresentação são também importantes para que o vídeo possa se constituir como um instrumento de aprendizagem e de desenvolvimento humano. 


\section{As línguas e os modos de aprendizagem}

Os movimentos sociais dos surdos, cada vez mais fortes e embasados em seus próprios estudos, vêm propondo para a sociedade e, principalmente, para a educação, a desconstrução da ideia do "surdomudo" como um sujeito de "falta". Em seu lugar, propõe-se um sujeito de característica culturais específicas e pertencente a um grupo de características linguísticas diferente da maioria. Ao perder a audição, a criança surda passará a ter na experiência visual o canal principal de apreensão do mundo e também de uma língua que lhe permitirá o acesso às dimensões simbólicas, conceituais e comunicativas da vida: a língua de sinais (PEDALINO, 2009). A pessoa surda terá, assim, construída "sua identidade em torno dessa diferença linguística e cultural, da qual depende para integrar-se na sociedade e na cultura" (BEHARES, 1993, P.20).

Vistos deste novo ângulo, os estudos de pesquisadores surdos como Perlin (2006), Stumpf (2009), Campello (2008), Strobel (2007) sugerem que, a partir da característica viso espacial da língua, será necessário pensar estratégias pedagógicas que visem atender a esta especificidade no espaço educacional do surdo. Entre essas estratégias, as novas tecnologias como vídeo, internet, celulares com câmeras, webcam se colocam como instrumentos cuja potencialidade educacional e, principalmente, de interação e inclusão para estes sujeitos no espaço escolar, tem ganhado destaque (CAMPELLO, 2008).

Historicamente, o uso de mídias na educação de surdos sempre esteve presente, mesmo quando a educação estava mais voltada para o português na modalidade oral. Naquele momento, o uso da mídia tinha como objetivo fazer o surdo chegar o mais próximo possível do ouvinte, portanto, os recursos utilizados buscavam favorecer a oralização e/ou apropriação da língua portuguesa falada. Mesmo com a falta de percepção de sons e da fala dos personagens, o uso de filmes está presente na sala de aula do surdo há algum tempo. Numa das publicações do INES, em 1954, a professora Ana Rímoli de Faria Doria dizia que o recurso visual é indispensável ao trabalho educativo, pois, segundo a sua concepção, ele é o estímulo sensorial que integra a educação, complemento precioso e necessário ao professor especializado (ROCHA, 2005). Segundo ela, este recurso tem como finalidade principal permitir que o surdo tenha acesso ao conhecimento, entretanto deve ser usado criteriosamente. Acreditando no material visual para o desenvolvimento da criança surda e, com isto, fornecendo-lhe oportunidade de adquirir hábitos e atitudes que facilitam sua integração ao grupo social, os jogos, as atividades espontâneas e os filmes têm sido utilizados na prática pedagógica com os alunos. A professora Ana Rìmoli já apontava na década de 50 que o canal natural de ensino- aprendizagem da criança é o visual e que será, preferencialmente, por ele que os conteúdos escolares serão apreendidos a partir de materiais didáticos com características audiovisuais.

O uso de material predominantemente visual na educação de crianças surdas é também discutido por Reyle (2003, p. 16), a partir de sua experiência de ensino e pesquisa em arte- 
educação. A autora afirma que "[...] crianças surdas em contato inicial com a Língua de Sinais necessitam de referências da linguagem visual com as quais tenham possibilidade de interagir, para construir significado". A mesma autora acrescenta, ainda, outra função para a imagem, lembrando que existe um aspecto lúdico na mesma, que chama a atenção e aguça a curiosidade, aspectos fundamentais para a educação de surdos. Pode-se compreender que a experiência visual terá função de instrumento de mediação da aprendizagem em sala de aula, para que os alunos surdos possam transformar por meio de processamento das imagens (estabelecendo generalizações, comparações, relações) as estratégias cognitivas concretas em estratégias cognitivas simbólicas (NERY e BATISTA, 2004; GOMES, 2012).

Sabemos que o que prevalece na escola é a língua portuguesa oral nos anos iniciais e depois a escrita, mas com relação aos surdos já sabemos que o domínio desta língua, seja na modalidade oral ou escrita, será um processo longo (VIANA, 2010). Assim, a língua de sinais deverá estar presente não só nos agentes da escola como também nos materiais produzidos, para permitir o acesso do surdo ao mundo do conhecimento.

A compreensão sobre o lugar que a língua de sinais ocupa para a formação da pessoa surda foi um avanço importante, mas agora devemos pensar como trabalhar com as duas línguas na cena educacional com uma proposta pedagógica que contemple a especificidade linguística do surdo, na verdade, as especificidades linguísticas dos diferentes perfis linguísticos apresentados por surdos num mesmo ambiente educacional. Vivemos agora um momento de fazer avançarem as discussões sobre a surdez no sentido da construção de práticas pedagógicas que favoreçam as questões implicadas no desenvolvimento do aluno surdo.

De acordo com Moran (1995), a força da linguagem audiovisual está no fato de ela transmitir as mensagens simultaneamente por mais caminhos do que conscientemente percebemos. Parte do concreto para o abstrato, do imediato para o mediado pela ação, da reflexão da produção para a teorização. A imagem, povoada de história, permite trazer para a sala de aula sensações e percepções envolvendo o espectador/aluno e construindo uma nova

realidade que tem como objetivo a ampliação do seu capital cultural e de experiências (BLASCO et al., 2005). Na educação de surdos, a apresentação dos conteúdos curriculares por meio de imagens tem se tornado cada vez mais uma necessidade na prática pedagógica (ROCHA, 2012).

\section{Referencial Teórico}

Ferreira (2006), ao fazer uma revisão sobre os estudos de recepção, relata que na década de 50 a visão que se tinha do receptor era de alguém que seria preenchido pelos conhecimentos e conteúdos emitidos pelo emissor. A partir de 1980, se desenvolve a concepção, iluminada pelos os estudos de recepção e Estudos Culturais, segundo a qual o receptor é um sujeito ativo no processo de comunicação e a produção de sentido um processo eminentemente polissêmico, já 
que permite várias leituras por parte do receptor. Os estudos de Sol Worth (1979), em uma abordagem antropológica e pragmática da comunicação, consideram que um filme não tem sentido em si mesmo, porque adquire sentido apenas na relação com o sujeito que o percebe. Assim, segundo esse autor, a comunicação não deve ser vista como transmissão de mensagem, e sim como um duplo processo de produção de sentidos.

Assim, o produto midiático, ao ser "lido" por um grupo determinado, poderá suscitar diversos significados, pois de acordo com Hall (2000) não existe uma relação unidirecional de produção de sentido/significado entre produtor e receptor, e sim uma circularidade de sentidos/significados, entre produtor e receptor. Essa circularidade é definida pelo fato de que, na circulação social dos bens, os produtores buscam compreender os desejos, valores e cultura dos receptores, tanto quanto estes buscam compreender e entrar em sintonia com os processos de leitura desencadeado pelas obras audiovisuais.

A circularidade do processo de comunicação nos remete a ideia de "endereçamento", ou seja, ao fato de que as obras audiovisuais são produzidas para um público mais ou menos específico e previamente pensado. Ellsworth (2001), a partir dos estudos sobre o cinema feminista, trabalha com esse conceito para indicar o caráter inevitável de se endereçar qualquer comunicação, texto ou ação para alguém. Ao supor quem é o público a quem se destina o filme, o produtor irá construir uma estrutura fílmica utilizando-se da narrativa, cenário, vestuário, imagem, sons e posicionamento de câmera para atrair e convocar o espectador a uma leitura desejada, ou o mais próximo possível desta. No entanto, não podemos esquecer que a experiência humana se constitui de uma diversidade de categoriais sociais, motivo pelo qual a autora chama atenção para o fato de que mesmo que um filme seja endereçado a um público idealizado previamente, o espectador pode não assumir o lugar determinado para ele, assim como o filme pode não ser o que ele esperava. Neste desencontro, o endereçamento se reconfigura e reorganiza a relação entre produtor e espectador, entre intenção e leitura. Para a autora, o espectador também se configura num sujeito ativo na hora em que está diante de um produto midiático fazendo ajuste na sua leitura. Mesmo com estes ajustes, podemos entender a colocação de Odin (2005) ao apontar que o espectador não é totalmente livre na sua leitura, pois o endereçamento irá mediar de alguma maneira os sentidos que serão construídos no momento da recepção.

Hall (2003) também traz a ideia de uma audiência que interpreta ativamente o conteúdo midiático, pois considera que a pluralidade de recepção está baseada na diversidade cultural que é responsável por distintas formas de apropriação e consumo dos produtos de massa (COSTA, 2012). Para Hall (2003), os produtos midiáticos, como os programas televisivos, possuem textos relativamente abertos que podem ser lidos de diferentes maneiras por diferentes pessoas que estão inseridas em diferentes contextos sociais e, portanto, terão posições de leituras que correlacionam experiência social e os sentidos construídos sobre o programa de televisão. Nesta 
proposta, não teríamos uma imposição de poder da mídia frente ao espectador, pois os processos de codificação e decodificação possuem certas determinações, mas também momentos de relativa autonomia por parte do receptor/espectador (COSTA, 2012).

Outros conceitos fundamentais para Hall (2003) dizem respeito à diferenciação entre leitura preferencial e significado preferencial. O significado preferencial diz respeito à codificação. O produtor, ao conceber um filme, o faz a partir de certas conviç̧ões sobre para quem é o filme e o que dele será importante ser apreendido (codificação). Quando o receptor apreende cada significado do modo pretendido, Hall considera que existe um posicionamento de concordância do espectador em relação ao filme, e este terá realizado uma leitura preferencial.

Ao ser produzido, o significado preferencial (ou seja, o significado da obra tal como imaginado pelo produtor) terá certo poder sobre a leitura do receptor, pois as decodificações acontecem dentro dos domínios da codificação, ou seja, as escolhas feitas pelo produtor com relação aos planos, edição, localização da câmera, cenário, entre outros elementos fílmicos, condicionam a leitura do espectador no momento da decodificação. Mesmo assim, não é possível se falar em determinismo, coloca Hall, pois ao estar diante do espectador o texto fílmico escapará das mãos de seu autor e as leituras pode ser realizadas em diferentes posicionamentos.

Ao considerar a pluralidade cultural um fator que interfere no posicionamento do espectador, o autor identifica o momento da recepção como um espaço de negociação entre o desejado pelo produtor e o posicionamento adotado pelo espectador. Aponta três possibilidades de posicionamento do espectador frente ao produto de massa: (1) dominante ou preferencial em que a leitura corresponde quase que integralmente ao modo como ela foi codificada, como apontado acima; (2) de oposição - quando o espectador está completamente contrário ao sentido pretendido na mensagem, ou seja, um ponto de vista oposicionista que irá retirar do texto exatamente o oposto do pretendido; (3) negociada - quando o espectador compreende a proposta do produtor, mas sua leitura está baseada numa estrutura de referencia alicerçada por uma experiência social diferente da pretendida pelo produtor.

Schroder (2000) trouxe uma proposta complementar ao modelo de Hall. Observa que o modelo de Hall foi construído dentro de um quadro teórico marcado pela unidimensionalidade, em virtude da ênfase dada as questões ideológicas da recepção. Schroder propõe um modelo em que considera que fatores macro sociais como raça, classe e gênero, e micro sociais como escolaridade, cultura, posição política e outros estarão em jogo no momento da recepção fazendo com que não exista apenas uma leitura. Dessa forma, constrói a partir do modelo unidimensional de Hall, um modelo multidimensional que permite capturar processos que estejam ocorrendo simultaneamente no momento da recepção. O modelo inclui as dimensões de motivação, compreensão, discriminação, posição, avaliação e implementação, que estão relacionadas às experiências subjetivas relacionadas ao contexto situacional em que o significado foi produzido (SCHRODER, 2000). 


\section{A pesquisa}

Para investigar a leitura dos professores sobre o vídeo educativo em Libras "Sinalizando a Sexualidade" (INES, 2000), em um espaço inclusivo, nossa pesquisa buscou, num modelo de "visão holística", a interrelação entre produção e recepção, entendendo que estes dois processos acontecem em momentos distintos e com características próprias, mas que podem ser compreendidos como atividades que criam situações de mediação de produção de significado.

Para o desenvolvimento do trabalho foi realizada uma análise da obra de acordo com as etapas da análise fílmica francesa, ou seja, um estudo das características técnicas e estéticas do vídeo analisado e de seu significado, com base nos autores Vanoye e Goliot-Lété (2011). Este estudo nos permitiu especificar os conteúdos e mensagens trabalhadas explícita ou implicitamente no vídeo pesquisado.

Para ampliar os resultados da análise fílmica, foram realizadas entrevistas com os idealizadores e produtores do vídeo, que tiveram a oportunidade de expor informações sobre as condições de produção do vídeo e suas intenções. O questionário aplicado buscou obter informações sobre como os produtores explicam o significado preferencial, assim como o endereçamento, na sua perspectiva.

Conhecendo a obra e o que os seus produtores desejam com ela, o passo seguinte do trabalho foi buscar as leituras dos professores para sabermos o quanto o que foi pretendido por seus produtores fica ou não explícito nas leituras realizadas pelos professores. Foram entrevistados professores de uma escola estadual, situada no município de Niterói. Criada em 1835, com a denominação de uma Escola Normal, foi a primeira no Brasil e das Américas, para formação de professores para a instrução do ensino primário. Foram várias as reformas ao longo de seus 175 anos de existência, relacionadas com as mudanças políticas de educação e de governo. Atualmente atende desde o Ensino Fundamental até o Ensino Médio com a formação de professores. Ao longo da sua história sempre recebeu crianças e adolescentes com deficiência. A escola atende hoje crianças e jovens surdos, além de cegos e cadeirantes. Possui diversos espaços dedicados a esse público, entre eles a sala multifuncional, criada em 2001, uma demanda da Secretaria de Educação Especial/SEESP para o atendimento educacional especializado aos alunos com necessidades educacionais especiais, de forma a garantir o acesso e a permanência desses na classe do ensino regular.

Após uma conversa inicial com os professores sobre os objetivos do trabalho, o vídeo foi disponibilizado para que eles pudessem assistir e, em seguida, responder ao questionário e enviar o resultado, por e-mail, para os pesquisadores. Foram enviados doze questionários e obtivemos o retorno de sete participantes. 
O questionário aplicado abrangeu dois grupos de questões: o primeiro buscando dados quantitativos com relação à prática e formação dos professores, e o segundo, questões mais abertas que objetivavam que o professor fizesse sua avaliação sobre o material a ser analisado. As questões envolviam a temática do vídeo, os principais conflitos apresentados, a narrativa e mudanças que indicariam para a melhor realização ou adequação do vídeo.

A análise dos conteúdos das respostas nos permitiu agrupá-las em respostas referentes ao tempo de atuação e formação dos professores, tipo de comunicação utilizada com seu aluno surdo, formação sobre mídias e o seu uso efetivo em sua sala de aula. Sobre o vídeo "Sinalizando a Sexualidade", permitiu obter informações sobre como os professores identificaram a temática, o posicionamento dos produtores e as leituras feitas por eles naquela ocasião.

\section{Resultados}

\section{Análise fílmica}

Tendo como cenário principal a escola, o vídeo apresenta alguns conflitos vivenciados por dois casais de jovens envolvendo questões sobre a primeira relação sexual de uma jovem e gravidez indesejada. Mostrando os aspectos anatomofuncionais do corpo do homem e da mulher, o vídeo traz informações para que os jovens conheçam o seu próprio corpo. O contexto histórico da produção do vídeo diz respeito às indicações do Ministério da Saúde com relação à divulgação de informações sobre a prevenção das DST's e a importância do sexo seguro. Essa divulgação visava especialmente o jovem surdo, razão pela qual os protagonistas são jovens surdos e o vídeo utiliza LIBRAS e legendas em português.

Para este trabalho, destacamos apenas a análise de algumas sequências de forma a apontar algumas opções adotadas pelos produtores quanto à construção do endereçamento e do significado preferencial. Na sequência da sala de aula, por exemplo, com uma dinâmica de pergunta e resposta, o personagem da professora conduz uma dinâmica em que as informações propostas pelos produtores são colocadas. Os alunos colocam questões como:

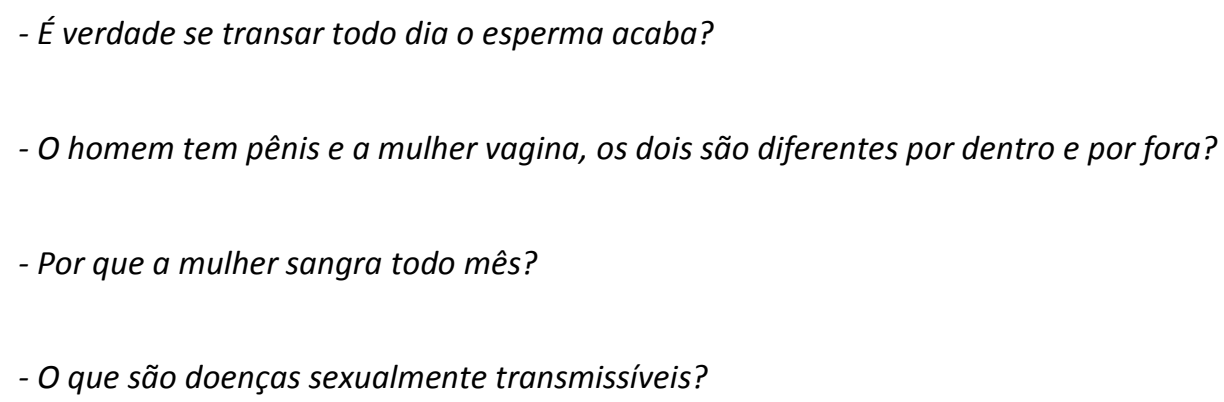


Usando a Libras como língua de instrução, a professora responde às perguntas fazendo uso de recursos visuais tais como esquemas simples ou animação que mostram a anatomia e a fisiologia do corpo seja do homem ou da mulher. Ao abordar somente os aspectos orgânicos sobre as questões sexuais, a professora não trata das questões subjetivas (psicológicas) que acompanham as mudanças corporais e hormonais nesta fase de vida como, por exemplo, aceitação do novo corpo, a transformação nas relações com indivíduos de ambos os sexos, a adoção do papel sexual masculino e feminino, independência emocional dos pais e de outros adultos entre outras.

Em outra sequencia, ao ser procurado pela jovem que está grávida e sua amiga, o personagem/médico busca uma maneira bem didática, utilizando-se de imagens e objetos reais, tais como a camisinha masculina e uma cartela de pílula, passar informações sobre os métodos anticoncepcionais, os cuidados na gravidez e as doenças sexualmente transmissíveis. O médico, nas suas orientações, reforça e complementa a fala da professora:

Jovem grávida: Eu posso transar normalmente?

Médico: Você deve ter uma vida sexual tranquila. É importante que você faça uma alimentação com frutas, verduras, legumes, beber leite e comer carne. Ter uma atividade física é saudável para você e o seu bebê.

Jovem grávida: Eu preciso voltar ao consultório só na hora de ganhar o neném?

Médico: Você precisa vir ao médico, mês a mês até completar os nove meses. E eu vou estar te consultando, vendo como está o bebê dentro da sua barriga através da ultrassonografia e os batimentos cardíacos para um bom desenvolvimento do feto.

Na cena final do vídeo existe a indicação de questões para discussões e debates que os professores poderão propor após a sua apresentação em sala de aula. Neste sentido, o material possui um endereçamento não só para o surdo, mas também para o professor. Considerando que o surdo possui uma lacuna nas informações sobre a sua própria saúde e também no que diz respeito à sua sexualidade, o vídeo busca sensibilizar e informar a comunidade surda para os temas da gravidez indesejada, a primeira relação sexual e as doenças sexualmente transmissíveis possibilitando que o adolescente surdo tenha maior conhecimento do seu corpo e possa tomar decisões sobre as situações que envolvam a sua sexualidade.

A escolha pela escola do INES como cenário permitiu que o vídeo criasse diversas situações de encontro dos jovens protagonistas, em que são abordadas as principais dúvidas e questões relacionadas à saúde reprodutiva e vida sexual do jovem surdo, por sinal, similares as de 
quaisquer outros jovens. A escola é mostrada como um espaço importante na construção da identidade dos jovens, e as trocas e confrontos vivenciados vão permitindo as identificações e o respeito ao outro.

\section{Entrevista com os produtores}

Participaram da produção do vídeo, uma professora de Biologia do INES e dois profissionais surdos (que trabalharam na construção de roteiro e acompanhamento das gravações e edição). O vídeo foi produzido no ano 2000 por uma empresa produtora de mídia, que se responsabilizou pela gravação, edição e replicação do material. Nesta pesquisa, apenas conseguimos entrevistar o dono da empresa, que falou sobre o desafio de produzir um material audiovisual com atores surdos que utilizavam outra língua, e a professora de Biologia do INES.

A entrevista com a professora de Biologia nos permitiu saber que a proposta de produção do vídeo sobre sexualidade surgiu a partir das atividades desenvolvidas em oficinas de saúde no Colégio de Aplicação do INES. A recorrência nas dúvidas dos alunos levou a professora a propor ao Instituto a produção de material audiovisual para ser disponibilizado não só no INES, mas também em outras escolas com adolescentes surdos. Foi determinado que os conceitos a serem apresentados no vídeo fossem as dúvidas sobre sexualidade do cotidiano dos alunos, tais como o uso da camisinha, menstruação, relação sexual e gravidez.

A professora explicou que escolheu trabalhar com atores surdos buscando a identificação do espectador surdo com os personagens e a consequente aceitação dos conteúdos apresentados. $\mathrm{O}$ uso da Libras, com legendas em português, se deveu ao mesmo motivo. Para atender a este público que tem como primeira língua a de sinais e segunda língua, o português, optou-se pela língua de sinais como a língua dos personagens. Mas para atender aos surdos que possuem como primeira língua o português e os ouvintes com dificuldade de aprendizagem foi feito uso de legenda, numa linguagem coloquial, com uma sintaxe simplificada. A escolha pela fiç̧ão como modo de apresentar o tema tinha como proposta contextualizar as informações sobre sexo seguro, facilitando assim a compreensão pelo surdo.

Ainda segundo os produtores, o vídeo foi pensado para os surdos, pois é visual e permite que eles entendam melhor os conteúdos. Além disso, os ouvintes podem aprender a Libras e conhecer como é a cultura surda.

A ideia central do vídeo parece ser munir os espectadores de informações, permitindo que eles possam tomar suas próprias decisões frente às questões sobre sexo e sua sexualidade. Com relação aos personagens, eles foram construídos de forma que pudessem representar pessoas parecidas com os alunos, pessoas que fazem parte do dia a dia do surdo e que, de uma forma ou de outra, participam da construção da representação social sobre sexo/sexualidade para o sujeito surdo. Portanto para os produtores, o vídeo é endereçado principalmente à comunidade

R. B. E. C. T., vol 7, núm. 1, jan-abr.2014 ISSN - 1982-873X 
jovem surda que possuiria uma defasagem de informação sobre sua própria saúde em relação à comunidade jovem ouvinte.

Os produtores, ao considerarem que existe uma falta de informação entre os jovens surdos para as questões sobre sua sexualidade, buscou, com uma narrativa de modo ficcional, com atores surdos (e apesar de parecerem mais velhos que são os personagens que representam) e com a presença das duas línguas (língua de sinais e língua portuguesa) preencher essa lacuna. É significativo, no que diz respeito ao endereçamento, o fato de as informações aportadas pelo vídeo sejam aquelas que especialmente interessavam à comunidade surda jovem, conforme esclarecido pela professora de Biologia.

A partir do vídeo, espera-se que os jovens surdos, de posse das informações, possam se sentir mais seguros para tomar cuidados e decisões com relação a sua própria sexualidade.

\section{Análise dos questionários para os professores}

Dentre os sete professores pesquisados, dois são homens e cinco são mulheres. $O$ tempo de magistério destes professores varia de sete a trinta e dois anos, caracterizando um grupo de professores com uma experiência significativa. No grupo de professores pesquisados, seis atuam na sala regular (nas disciplinas de Ciências, Educação Física, Português, Literatura), ou seja, dão aula para os alunos com e sem deficiência na mesma sala. Dentre estes, cinco lecionam nas turmas do Ensino Fundamental 2 (do 6ㅇ ao 9o ano), um no Ensino Médio e dois atendem aos dois segmentos. Considerando que a escola segue as orientações da política de Educação Especial na perspectiva da Educação Inclusiva (2008), possui no seu corpo discente alunos com e sem deficiência. Uma professora atua somente no Atendimento Educacional Especializado (AEE), descrito na política para atender, em horário contrário ao da sala regular, os alunos com deficiência, transtornos globais do desenvolvimento e altas habilidades. 0 trabalho nesta sala visa conteúdos diversos e com estratégias diferenciadas que permitem atender as especificidades desses alunos. Dos sete professores, dois declararam que não tiveram na sua formação aspectos teóricos da Educação Especial/Inclusão, enquanto os outros cinco apontam que a sua formação inicial contemplou disciplinas nesta área e seguem os estudos na educação continuada.

Como possui atualmente cerca 33 alunos surdos, a escola vem cumprindo as diretrizes disposta na Lei de Libras (2002) para garantir a acessibilidade dos alunos aos conteúdos escolares, contratando os intérpretes que devem estar nas salas onde houver um aluno surdo. No entanto, é importante que se diga que a presença do intérprete não pode e nem deve substituir a relação que deve existir entre o surdo e o seu professor, bem como as estratégias que o professor deve utilizar, para que seu aluno surdo seja, de fato, participativo no seu processo de aprendizagem. A escola possui, hoje, sete intérpretes na parte da manhã, dois à tarde e quatro à noite. Perguntado 
aos sete professores se a mediação com os intérpretes acontece apenas no momento da aula, quatro professores disseram que a sua comunicação com o aluno surdo se dá por meio do intérprete. Destes, dois complementaram sua resposta dizendo que também utilizam figuras e um pouco de Libras. Outros dois professores utilizam Libras e o português para a comunicação e apenas um professor usa a Libras na sua comunicação com o aluno surdo.

Com relação à formação do professor para o uso de mídias na educação, dois professores responderam ter alguma formação e cinco responderam não terem nenhuma formação na área. Estas respostas vão de encontro ao que Araújo (2008) identifica como uma lacuna na formação do professor que vive no século XXI, porém não tem reflexões e nem debates na sua graduação sobre as estratégias de ensino com uso de materiais audiovisuais no seu dia a dia da sala de aula. Quando perguntamos aos professores sobre a utilização dos recursos visuais em sala, apenas dois disseram que não fazem uso. Sobre a frequência de uso, dos cinco professores que utilizam, dois sempre organizam suas aulas com o material audiovisual e três utilizam esporadicamente. Acreditamos que esta utilização esteja relacionada com o investimento da escola no que diz respeito ao espaço físico e aparelhagem, seja para utilização na sala de aula ou nos laboratórios de informática.

Quando na sala está presente um surdo, o material audiovisual é utilizado para dar acessibilidade a este aluno. Observamos isto na resposta do Professor1 ao dizer "[...] utilizo para facilitar a compreensão do surdo" ou do Professor 3 "[...] como ferramenta visual que facilite o entendimento do surdo sobre qualquer assunto". O Professor 5, que trabalha na sala multifuncional, diz que "[...] utiliza a mídia para registrar as atividades que os alunos desenvolvem, [...] ferramenta de pesquisa e incentivo à criatividade do grupo". Nestas falas observamos que a tecnologia é usada como proposto por Rizzo Júnior (2011), um elemento de transformação no processo educacional, em que o professor será um mediador da aprendizagem.

Sobre o vídeo, os professores identificaram o objetivo descrito pelos produtores, ou seja, que o material audiovisual busca sensibilizar os jovens sobre doenças sexualmente transmissíveis, gravidez na adolescência e os cuidados com a primeira relação sexual. Sobre a indicação pelos professores dos conflitos presentes no vídeo os sete professores apontaram: gravidez na adolescência, preocupação com prevenção das DSTs e a primeira relação sexual da jovem. Parece estar claro para os professores do que se trata o vídeo.

Mas também apareceu na resposta de três professores a indicação de que valores sociais sobre virgindade, aceitação da gravidez e a falta de opinião própria sobre sexualidade interferem nas atitudes dos jovens. Estes são pontos que permeiam as ações dos jovens com relação à descoberta da sua própria sexualidade. Ao identificarem os conflitos apresentados pelos produtores, os professores parecem compreender que a intenção do vídeo é chamar a atenção para as consequências e cuidados que os jovens devem ter nestes tempos de descoberta da sua própria sexualidade. Os professores, ao indicarem as questões sociais (família e amigos da escola) 
percebidas no vídeo, demonstram entender que o contexto em que cada um está inserido irá determinar também suas atitudes.

Os sete professores concordam que este é um material que deve interessar muito aos alunos, pois a temática traz questões que estão presentes não apenas no dia a dia da escola, mas também na família. O Professor 6 considera que este é um vídeo que interessa tanto para os surdos quanto para os ouvintes.

Para sabermos o quanto os professores se identificaram com a forma como a personagem da professora abordou o tema da sexualidade em sala de aula, questionamos sobre a sequência da aula de Biologia. Houve uma concordância dos sete professores que o tema foi bem abordado na aula e com explicações claras. Isto demonstra que a leitura esteve de acordo com o significado pretendido pelos produtores. No entanto, dois professores acrescentaram à sua resposta pontos que nos permitem pensar que para eles foi necessário um ajuste ou um posicionamento de negociação para a leitura envolvendo a narrativa e a estética do vídeo. 0 Professor 6, embora concorde, propõe uma dinâmica diferente para a aula:

Não sei se antes das perguntas a professora deu uma aula sobre o assunto, ou mesmo teve alguma palestra. Acredito que primeiro as informações devam ser oportunizadas para os alunos, para só então, abrir para um círculo de debates (Professor 6).

Talvez pelo caráter teatral da narrativa e por sequências mais longas principalmente nas cenas da sala de aula e do consultório médico, o Professor 2 tenha considerado o vídeo lento. Esta questão levou-o a uma posição negociada, ou seja, demonstra um posicionamento crítico sobre a estética do vídeo, embora esteja de acordo com a forma como a narrativa foi composta:

Concordo com a estratégia da professora, embora tenha achado o vídeo muito lento $e$ cansativo (Professor 2).

Com relação a modificar o vídeo, quatro professores fizeram colocações envolvendo tanto o que diz respeito ao tema, como à estética do vídeo. o professor 2 propõe modificar exatamente o que the havia incomodado antes (a duração do vídeo), e acrescentou um outro aspecto , o tempo de apresentação da legenda.

Eu faria as cenas com um pouco mais de agilidade. Também colocaria as legendas mais lentas, pois foi difícil acompanhá-las pela rapidez com que passavam (Professor 2).

Os Professores 3 e 1 propõem a discussão de outro tema: homofobia. 0 Professor 7 propõe a mudança do estilo de fiç̧ão para documentário, baseado na experiência que teve quando da exibição em sala de um documentário. Considera este estilo uma forma muito mais autoral e este talvez tenha sido o motivo pelo qual a experiência com este estilo tenha sido positiva tanto para os alunos surdos quanto para os ouvintes: 
Poderiam ser utilizados aspectos mais realísticos. Os alunos assistiram o documentário

"Meninas" e o resultado foi muito positivo tanto para os ouvintes como para os surdos.

Atribuo este resultado ao caráter realístico do documentário (Professor 7).

As respostas demonstram que os professores pesquisados tiveram uma leitura de concordância com relação à temática e os aspectos estéticos em geral do vídeo. Assim, perguntados sobre o seu posicionamento diante do vídeo, todos os professores responderam estar de acordo com a forma como o tema foi tratado. Posições mais negociadas ou críticas apareceram, no entanto, no que diz respeito a alguns aspectos da narrativa do vídeo, como apontado acima. Não foi questão para os professores o que na análise fílmica consideramos inadequado com relação à idade real dos atores e o que eles estavam representando. Também não houve aqui nenhuma referência ao fato de o vídeo ser narrado em Libras, fato este que, tanto na análise fílmica quanto na entrevista com os produtores, é uma característica importante de acessibilidade do vídeo para os alunos surdos.

\section{Conclusão}

Na Educação em Ciências e Saúde, e no que diz respeito à inclusão de alunos surdos, a utilização de recursos audiovisuais no espaço escolar ainda demanda pesquisas sobre sua produção e consumo. Para chegar ao objetivo de conhecer os sentidos construídos pelo professor da escola regular sobre o vídeo "Sinalizando a Sexualidade", o caminho percorrido da análise fílmica, entrevista com os produtores e, finalmente, com os professores nos permitiu conhecer em parte as características de produção e recepção deste material.

No estudo da produção, foi possível perceber que o vídeo possui o endereçamento para dois públicos: o jovem surdo e o professor. O significado preferencial está ancorado no reconhecimento de que o jovem surdo não possui informações sobre sua sexualidade. $\mathrm{O}$ vídeo buscou mudar esta realidade apresentando conteúdos relacionados a esse tema. Buscando uma estratégia de endereçamento para os professores, o vídeo utiliza o cenário da escola, elementos da narrativa (a linguagem pedagógica) e a representação do que se passa numa sala de aula de Biologia e no pátio da escola para que os espectadores se identifiquem com as práticas dos personagens.

Sabemos que, embora o produtor sempre tenha a intenção de direcionar o espectador na leitura dos textos midiáticos, os estudos vêm mostrando que este controle não é totalmente possível, pois o espectador está sempre ativo no momento da recepção destes textos e faz os ajustes necessários à sua leitura. Assim também ocorreu com os professores pesquisados, ainda que estes concordassem com o significado preferencial do vídeo, e que este busca informar e sensibilizar, principalmente, os jovens surdos sobre os temas relacionados à sexualidade. Essa leitura feita pelos professores/espectadores esteve de acordo com a intenção dos produtores, 
indicando um posicionamento de convergência em relação ao vídeo, ou seja, não existiu discordância com relação ao significado preferencial proposto pelos produtores (HALL, 2003).

No entanto, dois professores assumiram uma posição um pouco mais critica ao vídeo com relação à forma de abordagem do personagem da professora e ao ritmo das cenas e de aparecimento da legenda. Este posicionamento implicou numa leitura negociada por parte dos professores, pois apesar de terem observações sobre o vídeo, consideram que ele é um material audiovisual importante para o aluno surdo.

Como os produtores e os professores, achamos a informação um fator importante, para que os jovens possam lidar bem com a sua sexualidade - e o vídeo supre bem esta questão -, mas não devemos deixar de apresentar também outras questões psicológicas que estão implicadas no período da adolescência, como: a aceitação do corpo, a independência emocional, entre outros. A ausência destas discussões na narrativa deixou o vídeo muito mais direcionado à dimensão puramente biológica da sexualidade.

Os resultados deste estudo reafirmam, portanto, a aceitação e a importância que os professores atribuem ao material audiovisual e à imagem na educação de surdos e na sua inclusão na escola regular. Daí a importância de novos estudos que aprofundem o conhecimento sobre as possibilidades de leitura e de usos desses materiais na educação especial.

\section{Referências}

ARAÚJO, I. A. Mídias e formação de professores: percalços e alternativas. Revista Espaço: INES jul/dez no 30, 2008 p. 40-47.

ARROIO, A. \& GIORDAN, M. O vídeo educativo: Aspectos da organização do ensino. Química Nova na Escola, n. 24, nov. 2006. p. 8-11.

BEHARES, L. E. Nuevas corrientes en la educación del sordo: de los enfoques clínicos a los culturales. Cadernos de Educação Especial,Santa Maria:Universidade Federal de Santa Maria, 1993, 1 (4): 20-53.

BÉVORT,E.; BELLOTI, M. L. Mídia - Educação: Conceitos, Historia Perspectiva

Educ.Soc., Campinas. vol.109, set/dez 2009, p. 1081-1102.

BRASIL. Senado. Substitutivo ao projeto de lei da Câmara 103, de 2012 (PL 8.035, de 2010, do Executivo). Estabelece o Plano Nacional de Educação e dá outras providências. Brasília: Senado Federal, 2013.

BLASCO P, GALLIAN D, RONCOLLETA A, MORETO, G. Cinema para o estudante de medicina: um recurso afetivo/efetivo na educação humanística. Rev. bras. educ. med. 2005.p.29

CAMPELLO, A. R. S. Pedagogia Visual na Educação de Surdos-Mudos. Tese de doutorado da Universidade Federal de Santa Catarina: Florianópolis, 2008. p. 166.

156 DOI: 10.3895/S1982-873X2014000100008

R. Bras. de Ensino de C\&T 
CAMPELLO. A. R. S. Pedagogia visual/Sinal na Educação de Surdos. In: Estudos Surdos II. Quadros. R. M(org.) Arara Azul 2007. p. 100-131.

COSTA, J. H. Stuart Hall e o modelo"encoding and decoding": por uma compreensão plural da recepção. Revista Espaço Acadêmico.Universidade de Maringá, Paraná v.12, n.136, 2012. p111120.

ELLSWORTH, E. Modos de Endereçamento: uma coisa de cinema. In: SILVA, T. T. (org). Nunca fomos humanos: metamorfoses da subjetividade contemporânea. Belo Horizonte: Autêntica, 2001.

FERREIRA, C. A. M., ALVES, C. N. A imagem e o esquema corporal do sujeito com necessidades especiais. In: FEREIRA, C. A. M. \& RAMOS, M. I. B. B. Psicomotricidade Educação Especial e Inclusão Social. Rio de Janeiro (Org.) Rio de Janeiro: WAK. 2007. p. 27-40.

FERREIRA, T. Estudos Culturais, Recepção e Teatro: Uma articulação possível? Revista de História e Estudos Culturais. Fênix, Rio Grande do Sul, vol. 3ำ ano III no 4, 2006.

GOMES, L. F. Vídeos educativos - uma proposta para critérios de análise. Disponível em:http://www.unioeste.br/mestrados/letras.Acesso em: 31 mar. 2012.

HALL, S. Codificação/Decodificação. In: . Da diáspora: Identidades e mediações culturais. Belo Horizonte: UFMG, 2003, p.387-404.

Instituto Nacional de Educação Surdo. "Sinalizando a Sexualidade" Rio de Janeiro, Material audiovisual em DVD, 2000.

JUNIOR, S. A. R. Educação audiovisual: Uma proposta de formação de professores do ensino Fundamental e Médio no Brasil.Tese apresentada ao programa de Meios Audiovisuais da Escola de Comunicação e Artes do Doutorado Universidade de São Paulo, 2011, p. 189.

MINISTÉRIO DA EDUCAÇÃO. Política Nacional de Educação Especial na Perspectiva da Educação Inclusiva. Brasília, 2008.

MORAN, J. M. O vídeo na de sala de aula. Revista Comunicação \& Educação: Editora ECA Editora Moderna, São Paulo, 1995.

NERY, C.A.; BATISTA, C. G. Imagens Visuais como recursos pedagógicos na Educação de uma adolescente surda: Um Estudo de Caso. Pandéia no 14(29) 2004 p 287-299.

ODIN, R. A questão do público:uma abordagem semiopragmática In: Ramos,F (org) Teoria Contemporânea do Cinema. São Paulo, Senac, 205. P 27 -32.

PEDALINO, M. Uma experiência com crianças surdas. In: FEREIRA, C. A. M \& RAMOS, M. I. B. B.

Psicomotricidade Educação Especial e Inclusão Social. Rio de Janeiro: WAK, 2007. p.101-114. 
PERLIN,G. A cultura surda e os intérpretes de Língua de Sinais. ETD - Educação temática digital, Campinas, v. 7, n. 2, jun 2006. p.135-146.

REYLE, L. H. As imagens: o lúdico e o absurdo no ensino de arte para Pré- escolares surdos. In: I. R. Silva; S. Kauchakje \& Z. M. Gesueli (Orgs.), Cidadania, Surdez e Linguagem: desafios e realidades. Cap. IX (pp.161-192). São Paulo: Plexus Editora, 2003.

RIMOLI, A. Livro Comemorativo dos 97ํ Aniversário do INES-1954 (acervo do INES).

ROCHA, A.L.C. Elaboração de material didático: uma necessidade na educação de surdos. Monografia apresenta para espacialização na Universidade de Brasília, 2012 pag. 45.

ROCHA, S. O INES e a Educação de Surdos no BRASIL- Aspectos da trajetória do Instituto Nacional de Educação de Surdos em seu percurso de 150 anos. Rio de Janeiro: Instituto Nacional de Educação de Surdos, 2005. p. 140.

STUMPF, M. R. A educação bilíngue para surdos: relato de experiências e a realidade brasileira. In QUADROS, R. M.; STUMPF, M. R. Estudos Surdos IV. Petrópolis: Editora Azul, 2009 pag.426-450.

SROBEL, K. L. Histórias dos Surdos: Representações "Mascaras" das identidades surdas. In: QUADROS, R. M.; GLADIS, P. (Org) Estudos Surdos II. Arara Azul, Petrópolis, 2007. p.18-37.

VANOYE, F. \& GOLIOT-LETÉ, ANNE. Ensaio sobre a análise fílmica. Campinas: Papirus, 7ạed.2011. VASQUES, C. K.; BAPTISTA, C. R. A educação de sujeitos com transtornos globais do desenvolvimento: traços e circunstancia. In: BAPTISTA, C. R. (org.) Inclusão e escolarização múltiplas perspectivas. Porto Alegre: Mediação, 2006. p. 153-164.

WORTH S. The Uses of Film in Education and Communication. In: David RO, ed. Symbols: The forms of the expression, communication, and education, Part I, Seventy-third yearbook of the National Society for the Study of Education. Chicago: University of Chicago Press; 1979.

UNESCO. Declaração de Salamanca e linha de ações sobre necessidades educativas especiais. BRASILIA, 1994.

MARIA INES BATISTA BARBOSA RAMOS - Fonoaudióloga do Instituto Nacional de Educação de Surdos, Professora do Centro Universitário IBMR e Mestre em Educação em Ciências e Saúde (UFRJ) - maria.ramos@ibmr.br

LUIZ AUGUSTO COIMBRA DE REZENDE FILHO - É doutor em Comunicação e professor do Programa de Pós-Graduação em Educação em Ciências e Saúde do NUTES-UFRJ. É bolsista do programa Jovem Cientista do Nosso Estado (JCNE) da FAPERJ e líder do grupo de pesquisa Recepção Audiovisual em Educação em Ciências e Saúde (GERAES) - luizrezende@ufrj.br 